\title{
ALBUMIN METABOLISM IN PATIENTS WITH LYMPHOMA
}

\author{
By THOMAS WALDMANN, JERRY TRIER,* AND HAROLD FALLON $\dagger$ \\ (From the Metabolism Service and the Medicine Branch of the National Cancer Institute, \\ Bethesda, Md.)
}

(Submitted for publication July 30, 1962; accepted October 10, 1962)

Most patients with lymphoma have a reduced serum albumin concentration, often despite adequate nutrition and without evident liver disease or urinary protein loss (1-6). The etiology of this hypoalbuminemia is not clear. Possible causes include dilutional hypoalbuminemia, decreased albumin synthesis, increased albumin catabolism within the body, or excessive loss of albumin from the body through the kidneys or the gastrointestinal tract.

Steinfeld (7) studied the metabolism of $\mathrm{I}^{131}$ labeled albumin in twelve patients with neoplastic diseases, including one with lymphoma. The survival of albumin was normal or prolonged in these patients, whereas the albumin synthetic rate was reduced. This decreased synthetic rate was felt to be the primary defect leading to the hypoalbuminemia. Jarnum and Schwartz (8), however, demonstrated gastrointestinal protein loss in seven patients with hypoalbuminemia and gastric carcinoma by using I $^{131}$-labeled polyvinylpyrrolidone. They concluded that this loss of albumin was the cause of the hypoproteinemia seen in their patients and that deficient protein synthesis was not a significant factor. Gastrointestinal protein loss has also been reported in two patients with hypoproteinemia and lymphoma $(9,10)$.

In the present study, albumin metabolism was studied with $\mathrm{I}^{131}$-albumin in a series of patients with lymphoma to measure the plasma and total body albumin pools, as well as the rate of albumin degradation and synthesis. $\mathrm{I}^{131}$-polyvinylpyrrolidone (PVP) was used to determine if excessive gastrointestinal protein loss was present in these patients.

\section{PATIENTS}

Twenty patients were admitted to the National Cancer Institute with a diagnosis of lymphoma proven by bi-

\footnotetext{
* Present address : University of Washington School of Medicine, Seattle, Wash.

$\dagger$ Present address: University of North Carolina School of Medicine, Chapel Hill, N. C.
}

opsy who were capable of making the required urine and stool collections. An $\mathrm{I}^{131}$-albumin turnover study was performed on these patients during a period of active disease. They were hospitalized throughout the 4- to 6-week study, and their weights, temperatures, and caloric intakes were determined daily. Specific antitumor therapy was withheld during this period. ${ }^{1}$ Pertinent clinical data are recorded in Table I. The twenty cases included twelve patients with Hodgkin's disease, three with giant follicular lymphoma, three with lymphosarcoma, one with reticulum cell sarcoma, and one with chronic lymphocytic leukemia and lymphosarcoma. The fifteen men and five women studied ranged in age from 11 to 71 years. Except for Patients 2 and 14, each patient had an adequate caloric intake and a stable body weight during the study. Intermittent fever was present in six cases. Three patients had large bilateral pleural effusions and ascites. None had proteinuria or elevation of the blood urea nitrogen. Liver function tests revealed minor abnormalities in seven patients; five of these had increased levels of serum alkaline phosphatase. In Patient 17 hypercalcemia and bone lesions were prominent. Elevated levels of serum glutamic oxaloacetic transaminase were noted in Patients 4 and 14 ; Patient 14 had abdominal surgery 10 days before this determination, which may account for this abnormality. There was no clear explanation for these elevated levels in Patient 4.

The patients had a variety of gastrointestinal symptoms, including anorexia in seven patients, severe diarrhea in three, and abdominal pain in two. Patient 18 had steatorrhea with a fecal fat excretion of $18 \mathrm{~g}$ per day on a $100-\mathrm{g}$ intake. X-ray examination of his upper gastrointestinal tract showed considerable coarsening of the mucosal folds of the jejunum and ileum. Per oral biopsy specimens revealed dilated mucosal lymphatic channels. Patient 14 had a grossly distorted rigid stomach with irregular filling defects noted on X-ray studies. At laparotomy the entire stomach of this patient was found to be involved in an inoperable lymphomatous mass. Patient 20 had severe diarrhea and abdominal pain. At post-mortem examination there were numerous ulcerations of the stomach at the site of tumor nodules that extended through the wall of the lesser curvature.

The ten subjects used as controls for the $I^{131}$-albumin studies included six normal volunteers and four patients with idiopathic epilepsy.

\footnotetext{
1 One patient was receiving $200 \mathrm{mg}$ prednisolone.
} 
TABLE I

Clinical data on lymphoma

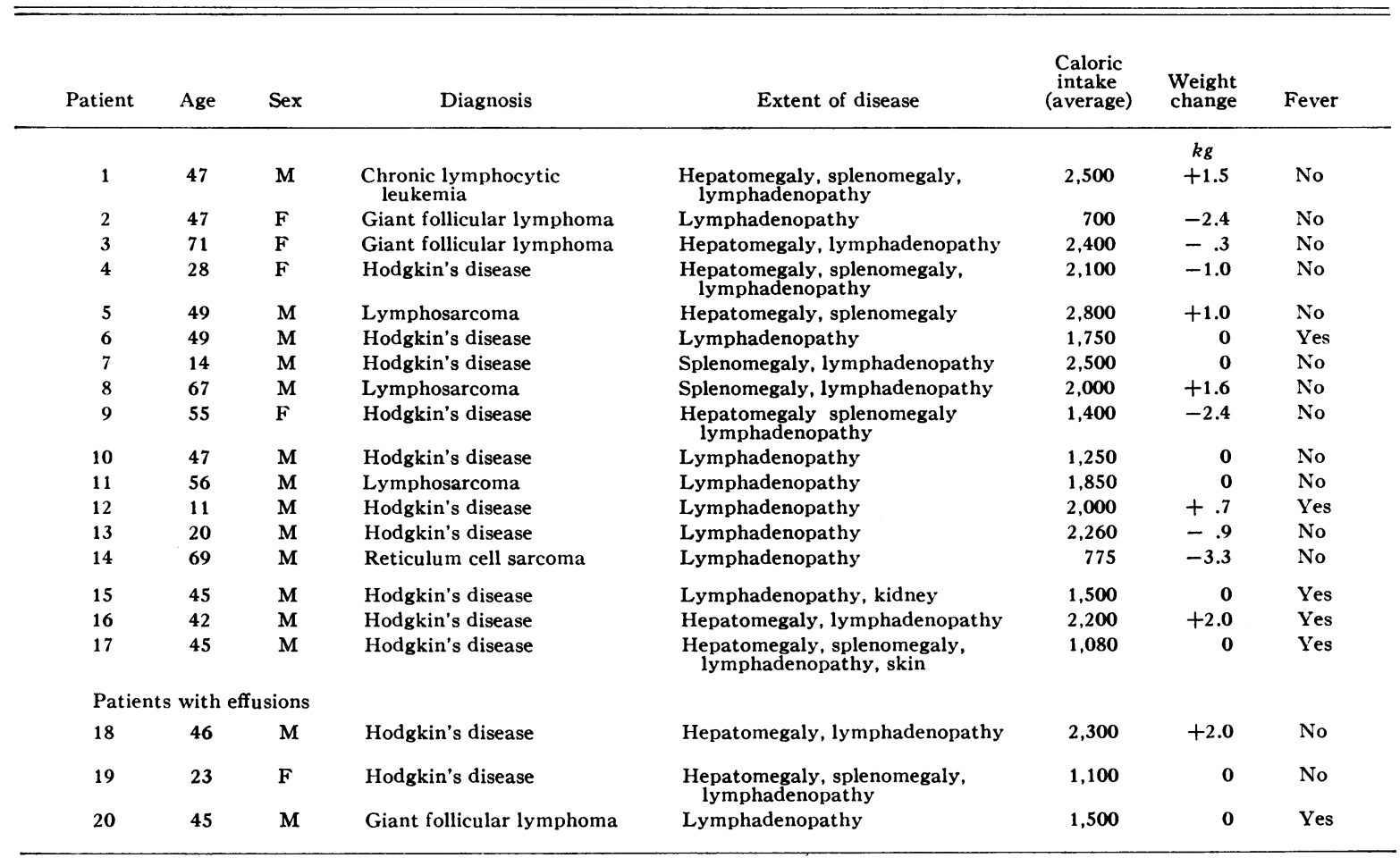

\section{METHODS}

$I^{131}$-albumin turnover. Thyroidal uptake of radioiodine released from breakdown of the labeled albumin was inhibited by the administration of $0.5 \mathrm{ml}$ of Lugol's solution every 8 hours throughout the study. Approximately $100 \mu \mathrm{c}$ of $\mathrm{I}^{131}$-albumin 2 was administered intravenously from a calibrated syringe to each patient. Blood samples were obtained without stasis from the patients at 15 and 30 minutes after administration of the iodinated albumin and then three times a week for the next 21 to 30 days, and placed in bottles with Versene anticoagulant. ${ }^{3}$ Quantitative 24-hour urine collections were obtained throughout the period of study. Stools were collected in 24-hour lots in paint cans for the first week of each study. The samples were assayed for radioactivity with appropriate standards in a well-type scintillation counter with a thallium-activated sodium iodide crystal. The total serum protein concentration was determined by a biuret method (11). Serum samples obtained weekly were analyzed by paper electrophoresis by a modification of a method of Henry, Goluk, and Sobel (12). There were no significant changes in the serum albumin concentrations in any of the patients throughout the period of study.

2 RISA T-4, Abbott Laboratories, Oak Ridge, Tenn. 3 Ethylenediaminetetraacetic acid tetrasodium salt.
Analysis of the data. The data were analyzed according to the methods of Berson, Yalow, Schreiber, and Post (13) and Steinfeld (14). In summary: plasma volume $=$ total activity administered/activity per milliliters of plasma at zero time (extrapolated from 15- and 30minute values), total circulating albumin = plasma volume $X$ albumin concentration, and total body radioactivity $=$ total activity administered minus the cumulative excretion of radioactivity in the urine and stools. The half-time survival $\left(\mathrm{t}_{\frac{1}{2}}\right)$ of $\mathrm{I}^{131}$-albumin was determined from the slope of a semilogarithmic plot of both the total body radioactivity and serum radioactivity against time (Figure 1). The fractional degradation rate $=0.693$ / $I^{131}$-albumin survival $t_{\frac{1}{2}}$ in days. After completion of the distribution phase of $\mathrm{I}^{131}$-albumin, the percentage of the body albumin that is intravascular may be estimated from: plasma volume $X$ plasma radioactivity per milliliter $\times 100 /$ total radioactivity retained in the body. The total body albumin pool $=$ total circulating albumin $\times 100 /$ per cent of body albumin that is intravascular. The albumin turnover $=$ total body albumin pool $\times$ fractional degradation rate determined from the whole body radioactivity curves. In the steady state, the grams of albumin degraded or lost per day, the albumin turnover, is equal to the albumin synthetic rate.

$I^{131}$-polyvinylpyrrolidone. $\mathrm{I}^{131}$-albumin entering the gastrointestinal tract is rapidly digested into the constituent amino acids and radioiodine and then absorbed. $\mathrm{I}^{131}$ 
TABLE I-(Continued)

patients studied with I $^{131}$-albumin

\begin{tabular}{|c|c|c|c|c|c|c|c|}
\hline Hemoglobin & $\begin{array}{l}\text { Gastro- } \\
\text { intestinal } \\
\text { symptoms }\end{array}$ & $\begin{array}{l}\text { Ceph. } \\
\text { floc. }\end{array}$ & $\begin{array}{l}\text { Thymol } \\
\text { turbidity }\end{array}$ & $\begin{array}{c}\text { Serum } \\
\text { glutamic } \\
\text { oxaloacetic } \\
\text { transaminase }\end{array}$ & $\begin{array}{c}\text { Serum } \\
\text { alkaline } \\
\text { phosphatase }\end{array}$ & $\begin{array}{c}\text { Bili- } \\
\text { rubin }\end{array}$ & $\begin{array}{c}\text { Choles- } \\
\text { terol }\end{array}$ \\
\hline $\begin{array}{c}\mathrm{g} / 100 \mathrm{ml} \\
11.0\end{array}$ & Pain & Neg. & $\begin{array}{c}\text { S.H. } U \\
0\end{array}$ & $\begin{array}{c}U / m l \\
27\end{array}$ & $\begin{array}{c}K .-A . U \\
12\end{array}$ & $\begin{array}{c}m g / 100 \mathrm{ml} \\
0.3\end{array}$ & $\mathrm{mg} / 100 \mathrm{ml}$ \\
\hline 13.0 & No & Neg. & 1 & 19 & 8 & 0.6 & 334 \\
\hline 12.3 & Diarrhea & Neg. & 2 & 13 & 10 & & 225 \\
\hline 13.0 & No & Neg. & 2 & 84 & 11 & 0.2 & 189 \\
\hline 11.9 & No & Neg. & 1 & 13 & 10 & 0.4 & \\
\hline 13.3 & Anorexia & Neg. & 2 & 36 & 24 & 0.4 & 282 \\
\hline 10.6 & No & Neg. & 2 & 26 & 14 & 0.2 & 183 \\
\hline 14.3 & Anorexia & Neg. & 1 & 24 & 6 & 0.7 & \\
\hline 9.0 & $\begin{array}{l}\text { Anorexia } \\
\text { Vomiting }\end{array}$ & Neg. & 1 & & 13 & & 310 \\
\hline 10.5 & Anorexia & Neg. & 2 & 20 & 9 & 0.3 & 178 \\
\hline 10.4 & No & $2+$ & 1 & 13 & 10 & 0.3 & 192 \\
\hline 11.8 & Pain & Neg. & 1 & 15 & 16 & 0.3 & \\
\hline 9.0 & No & Neg. & 3 & 10 & 13 & 0.2 & 125 \\
\hline 11.7 & $\begin{array}{l}\text { Anorexia } \\
\text { Pain }\end{array}$ & Neg. & 2 & 55 & 6 & 0.2 & 195 \\
\hline 13.8 & No & Neg. & 2 & 22 & 19 & 0.2 & 120 \\
\hline 10.0 & No & Neg. & 2 & 24 & 27 & 0.1 & 167 \\
\hline 9.4 & Anorexia & Neg. & & 20 & 64 & 0.3 & 180 \\
\hline 9.0 & $\begin{array}{l}\text { Diarrhea } \\
\text { Steatorrhea }\end{array}$ & Neg. & 1 & & 14 & 0.3 & 130 \\
\hline 9.1 & Anorexia & Neg. & 1 & 17 & 14 & 0.6 & 99 \\
\hline 9.5 & Diarrhea & Neg. & 1 & 23 & 11 & 0.3 & 200 \\
\hline
\end{tabular}

PVP,4 a macromolecule unaffected by intestinal enzymes, was therefore used to detect intestinal albumin loss according to the method of Gordon (15). The patients received 10 to $25 \mu \mathrm{c}$ of $\mathrm{I}^{131}$-labeled PVP intravenously from a calibrated syringe. The subsequent 4 days of stools were collected as a single lot in a paint can, homogenized on a shaker, and counted with an appropriate standard. The results are expressed as the percentage of administered tracer excreted in the 4-day fecal collection. The $\mathrm{I}^{131}$-PVP test was performed on 19 patients with lymphoma. Nine of these (Patients 3, 9, 10, 14, and 16 through 20) had also been studied with $\mathrm{I}^{131}$-albumin, including each of the patients with gastrointestinal symptoms or an $\mathrm{I}^{131}$-albumin survival $t_{\frac{1}{2}}$ of less than 14 days.

\section{RESULTS}

The results of the serum electrophoretic analyses are shown in Table II. The most striking feature is a reduction in the serum albumin concentration. Eighteen of the twenty patients had a serum albumin concentration below $3.5 \mathrm{~g}$ per $100 \mathrm{ml}$, the lower limit of the normal range. In

4 Prepared by the radiopharmaceutical service of the Pharmacy Department, National Institutes of Health, Bethesda, Md. (16). four patients the total serum globulin levels were increased. Nine patients had an $\alpha_{1}$-globulin level above $0.4 \mathrm{~g}$ per $100 \mathrm{ml}$, whereas six, five, and five patients, respectively, had serum $\alpha_{2}^{-}, \beta-$, and $\gamma^{-}$ globulin concentrations greater than normal; these were below normal in two of the patients. This was most marked in Patient 18, who had a significant reduction of all serum protein concentrations, with a marked reduction in the $\gamma$-globulin concentration to $0.16 \mathrm{~g}$ per $100 \mathrm{ml}$.

The results of the $I^{131}$-albumin degradation studies are shown in Table III. The total circulating albumin was low in all sixteen patients who had an albumin concentration below $3.5 \mathrm{~g}$ per $100 \mathrm{ml}$ at the time of the protein turnover studies. This indicates that the reduced serum albumin concentrations were not primarily due to plasma volume expansion. The total body albumin pool was below the normal range in thirteen of the patients who had no effusions. The subjects with effusions, however, had a marked decrease in the percentage of body albumin that was intravascular and had a normal or increased total body albumin pool. Thus, an abnormal distribution of 
albumin was a major factor in the marked reduction in serum albumin concentration seen in these patients with ascites and pleural effusions.

The fractional degradation rate of $\mathrm{I}^{131}$-albumin was normal in fifteen of the patients without effusions and slightly increased in two (Patients 9 and 16). The percentage of the body albumin pool degraded per day was significantly reduced in the three patients with protein-rich effusions. Fecal excretion of the radioiodine was negligible in all patients with a maximal daily fecal $\mathrm{I}^{\mathbf{1 3 1}}$ excretion of 0.04 per cent of the retained dose.
The albumin synthetic rate (albumin turnover) was reduced below that seen in the controls in fifteen of the patients, and appears to be the major factor in the hypoalbuminemia associated with lymphoma.

The percentage of the administered PVP excreted in the 4-day stool collection was normal for each of the patients with lymphoma studied, with a mean of 0.6 and a range of 0.4 to 0.9 per cent, compared to the mean and range in controls of 0.7 and 0 to 1.5 per cent, respectively. Patients with known gastrointestinal protein loss had a

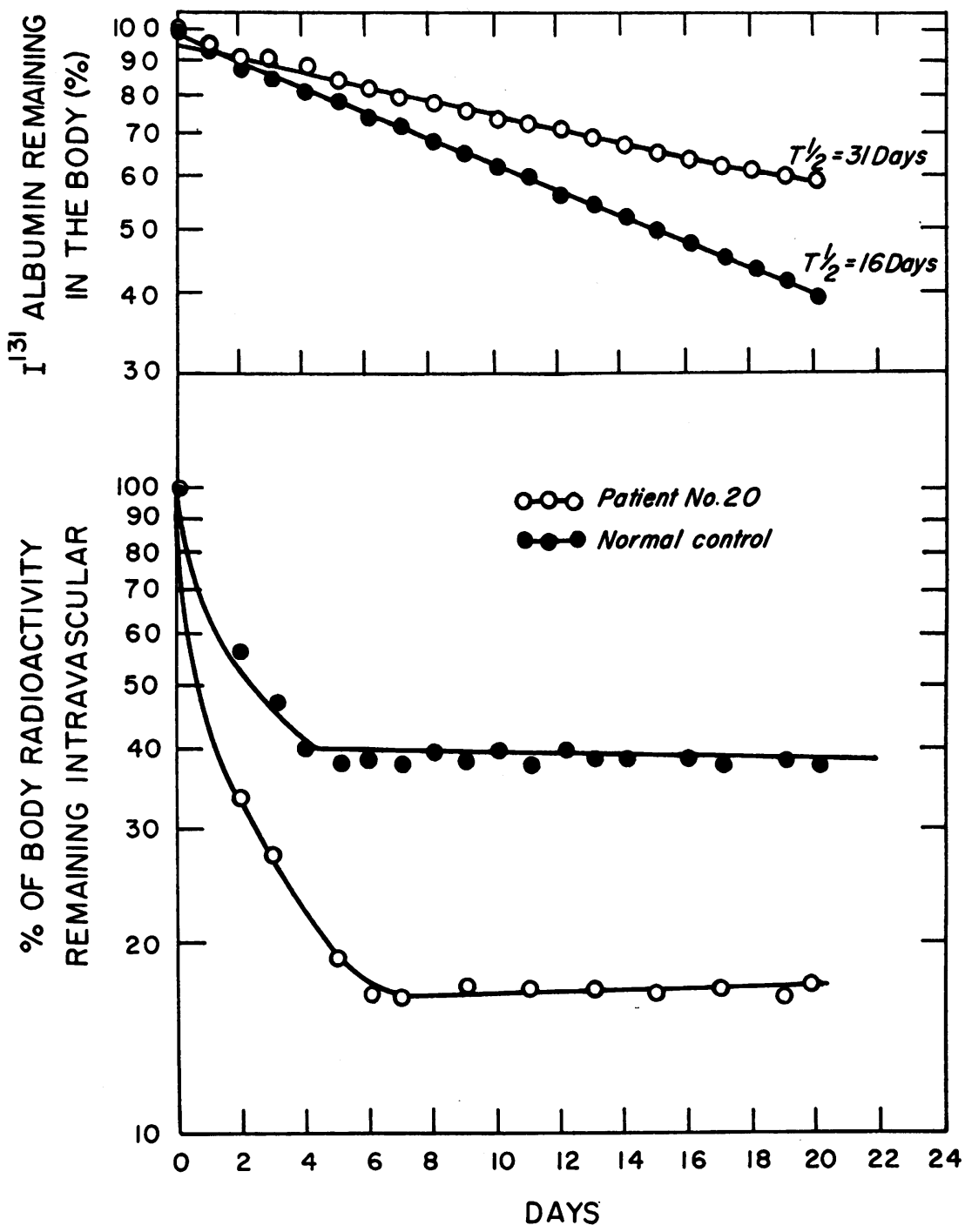

Fig. 1. Metabolism of $\mathrm{I}^{131}$-Albumin in a NoRmal control and in a patient WITH LYMPHOMA AND CHYLOUS EFfusions. The survival of $\mathrm{I}^{121}$-albumin is prolonged and the fraction of intravascular protein is decreased in the subject with effusions. 
TABLE II

Serum protein electrophoresis

\begin{tabular}{|c|c|c|c|c|c|c|c|}
\hline \multirow[b]{2}{*}{ Patient } & \multirow{2}{*}{$\begin{array}{c}\text { Total } \\
\text { protein }\end{array}$} & \multirow[b]{2}{*}{ Albumin } & \multicolumn{5}{|c|}{ Globulin } \\
\hline & & & Total & Alpha & Alphaz & Beta & Gamma \\
\hline & $\mathrm{g} / 100 \mathrm{ml}$ & $\mathrm{g} / 100 \mathrm{ml}$ & $\mathrm{g} / 100 \mathrm{ml}$ & $\mathrm{g} / 100 \mathrm{ml}$ & $\mathrm{g} / 100 \mathrm{ml}$ & $\mathrm{g} / 100 \mathrm{ml}$ & $\mathrm{g} / 100 \mathrm{ml}$ \\
\hline 1 & 5.6 & 3.8 & 1.9 & 0.3 & 0.6 & 0.5 & 0.5 \\
\hline 2 & 6.7 & 3.5 & 3.2 & 0.3 & 0.6 & 1.1 & 1.2 \\
\hline 3 & 7.4 & 3.4 & 4.0 & 0.4 & 0.9 & 1.0 & 1.8 \\
\hline 4 & 5.5 & 3.3 & 2.2 & 0.2 & 0.3 & 1.0 & 0.7 \\
\hline 5 & 7.0 & 3.2 & 3.8 & 0.4 & 0.9 & 0.9 & 1.6 \\
\hline 6 & 7.4 & 3.1 & 4.3 & 0.5 & 1.0 & 1.0 & 1.6 \\
\hline 7 & 9.6 & 3.2 & 6.4 & 0.7 & 1.4 & 1.6 & 2.7 \\
\hline 8 & 5.9 & 2.9 & 3.0 & 0.3 & 0.8 & 0.8 & 1.1 \\
\hline 9 & 6.4 & 2.8 & 3.6 & 0.5 & 0.8 & 1.2 & 1.2 \\
\hline 10 & 7.0 & 2.8 & 4.2 & 0.5 & 1.0 & 0.9 & 1.8 \\
\hline 11 & 7.2 & 2.8 & 4.4 & 0.5 & 0.7 & 0.9 & 2.4 \\
\hline 12 & $6.9^{*}$ & $2.7^{*}$ & $4.2^{*}$ & & & & \\
\hline 13 & 6.0 & 2.3 & 3.7 & 0.4 & 1.2 & 1.1 & 1.0 \\
\hline 14 & 5.3 & 2.2 & 3.1 & 0.5 & 0.7 & 0.9 & 0.9 \\
\hline 15 & 5.9 & 2.0 & 3.9 & 0.4 & 0.7 & 0.8 & 2.0 \\
\hline 16 & 7.6 & 1.7 & 5.9 & 0.4 & 0.7 & 1.7 & 3.0 \\
\hline 17 & 4.4 & 1.6 & 2.8 & 0.5 & 0.7 & 0.7 & 1.0 \\
\hline \multicolumn{8}{|c|}{ Patients with effusions } \\
\hline 18 & 4.0 & 2.6 & 1.4 & 0.2 & 0.4 & 0.6 & 0.16 \\
\hline 19 & 6.2 & 2.1 & 4.1 & 0.7 & 1.3 & 0.9 & 1.2 \\
\hline 20 & 5.1 & 1.9 & 3.2 & 0.6 & 1.1 & 0.9 & 0.7 \\
\hline $\begin{array}{r}\text { Normal } \\
\text { range }\end{array}$ & 6.3 to 8.5 & 3.5 to 5.5 & 2.8 to 4.2 & 0.20 to 0.40 & 0.51 to 0.93 & 0.64 to 1.06 & 0.74 to 1.70 \\
\hline
\end{tabular}

* Performed by dye method of Rutstein, Ingenito, and Reynolds (17).

TABLE III

$I^{131}$-albumin turnover in patients with lymphoma

\begin{tabular}{|c|c|c|c|c|c|c|c|c|}
\hline Patient & $\begin{array}{l}\text { Serum } \\
\text { albumin }\end{array}$ & $\begin{array}{l}\text { Plasma } \\
\text { volume }\end{array}$ & $\begin{array}{l}\text { Intra- } \\
\text { vascular } \\
\text { albumin }\end{array}$ & $\begin{array}{l}\text { Total } \\
\text { circulating } \\
\text { albumin }\end{array}$ & $\begin{array}{l}\text { Total } \\
\text { body } \\
\text { albumin }\end{array}$ & $\begin{array}{c}\text { Degrada- } \\
\text { tion rate } \\
\text { (whole body } \\
\text { curves) }\end{array}$ & $\begin{array}{l}\text { Degrada- } \\
\text { tion rate } \\
\text { (serum } \\
\text { curves) }\end{array}$ & $\begin{array}{l}\text { Albumin } \\
\text { turnover }\end{array}$ \\
\hline & $\mathrm{g} / 100 \mathrm{ml}$ & $m l / k g$ & $\%$ & $\mathrm{~g} / \mathrm{kg}$ & $g / k g$ & $\% / d a y$ & $\% / d a y$ & $\mathrm{~g} / \mathrm{kg} / \mathrm{day}$ \\
\hline 1 & 3.5 & 47 & 45 & 1.7 & 3.7 & 5.3 & 5.4 & 0.20 \\
\hline 2 & 4.4 & 38 & 40 & 1.7 & 4.2 & 5.0 & 5.0 & 0.21 \\
\hline 3 & 3.5 & 45 & 45 & 1.6 & 3.5 & 4.2 & 4.4 & 0.15 \\
\hline 4 & 2.8 & 40 & 36 & 1.1 & 3.1 & 4.6 & 4.9 & 0.14 \\
\hline 5 & 3.2 & 45 & 42 & 1.4 & 3.4 & 4.2 & 4.5 & 0.14 \\
\hline 6 & 3.5 & 48 & 40 & 1.6 & 4.0 & 3.7 & 3.2 & 0.15 \\
\hline 7 & 3.1 & 43 & 33 & 1.4 & 4.2 & 3.6 & 3.8 & 0.16 \\
\hline 8 & 2.9 & 37 & 37 & 1.1 & 2.9 & 4.6 & 4.8 & 0.13 \\
\hline 9 & 2.0 & 39 & 34 & 0.8 & 2.3 & 5.8 & 6.0 & 0.13 \\
\hline 10 & 2.6 & 45 & 40 & 1.2 & 2.9 & 4.6 & 4.2 & 0.13 \\
\hline 11 & 2.6 & 48 & 37 & 1.3 & 3.4 & 3.6 & 3.4 & 0.12 \\
\hline 12 & 2.9 & 43 & 37 & 1.3 & 3.4 & 4.1 & 4.6 & 0.14 \\
\hline 13 & 2.4 & 40 & 40 & 1.0 & 2.4 & 4.1 & 4.4 & 0.10 \\
\hline 14 & 2.4 & 40 & 34 & 1.0 & 2.8 & 4.9 & 5.0 & 0.14 \\
\hline 15 & 2.1 & 42 & 31 & 0.9 & 2.8 & 3.6 & 3.7 & 0.10 \\
\hline 16 & 1.7 & 45 & 41 & 0.8 & 0.9 & 5.8 & 5.9 & 0.11 \\
\hline 17 & 1.6 & 54 & 32 & 0.8 & 2.6 & 4.1 & 4.4 & 0.11 \\
\hline \multicolumn{9}{|c|}{ Patients with effusions } \\
\hline 18 & 2.1 & 50 & 39 & 1.0 & 3.6 & 3.2 & 3.4 & 0.12 \\
\hline 19 & 1.8 & 55 & 23 & 1.0 & 4.3 & 2.8 & 2.8 & 0.12 \\
\hline 20 & 2.1 & 51 & 19 & 1.1 & 5.7 & 2.1 & 2.1 & 0.12 \\
\hline 10 Controls* & {$\left[\begin{array}{c}4.0 \\
{[3.5 \text { to } 4.5]}\end{array}\right.$} & {$\left[\begin{array}{l}42 \\
{[35 \text { to } 50]}\end{array}\right.$} & {$\left[\begin{array}{l}41 \\
{[34 \text { to } 48]}\end{array}\right.$} & {$\left[\begin{array}{c}1.7 \\
{[1.5 \text { to } 2.0]}\end{array}\right.$} & $\begin{array}{c}4.1 \\
{[3.6 \text { to } 4.6]}\end{array}$ & {$\left[\begin{array}{c}4.1 \\
{[3.5 \text { to } 5.3]}\end{array}\right.$} & {$\left[\begin{array}{c}4.2 \\
3.6 \text { to } 5.3]\end{array}\right.$} & $\begin{array}{c}0.17 \\
{[0.15 \text { to } 0.20]}\end{array}$ \\
\hline
\end{tabular}

* Values represent the mean with the observed range in brackets. 
TABLE IV

Albumin of pleural fluid and serum in patients with effusions

\begin{tabular}{|c|c|c|c|c|c|c|}
\hline \multirow[b]{2}{*}{ Patient } & \multicolumn{2}{|c|}{ Serum } & \multicolumn{2}{|c|}{ Pleural fluid } & \multirow{2}{*}{$\begin{array}{l}\text { Time be- } \\
\text { tween ad- } \\
\text { ministration } \\
\text { of } I^{131} \\
\text { albumin and } \\
\text { thoracentesis }\end{array}$} & \multirow{2}{*}{$\begin{array}{l}\text { Specific } \\
\text { activity of } \\
\text { pleural-fluid } \\
\text { albumin/ } \\
\text { specific } \\
\text { activity of } \\
\text { serum albumin }\end{array}$} \\
\hline & Albumin & Globulin & Albumin & Globulin & & \\
\hline $\begin{array}{l}18 \\
19 \\
20\end{array}$ & $\begin{array}{c}\mathrm{g} / 100 \mathrm{ml} \\
2.0 \\
1.8 \\
2.2\end{array}$ & $\begin{array}{c}\mathrm{g} / 100 \mathrm{ml} \\
1.6 \\
3.6 \\
2.8\end{array}$ & $\begin{array}{c}\mathrm{g} / 100 \mathrm{ml} \\
1.3 \\
1.1 \\
1.6\end{array}$ & $\begin{array}{c}\mathrm{g} / 100 \mathrm{ml} \\
0.7 \\
1.7 \\
1.4\end{array}$ & $\begin{array}{l}\text { days } \\
14 \\
12 \\
9\end{array}$ & $\begin{array}{l}1.07 \\
1.12 \\
1.03\end{array}$ \\
\hline
\end{tabular}

fecal excretion of from 3.5 to 32.5 per cent of administered dose of this preparation of PVP. This suggests that gastrointestinal protein loss did not play a significant role in the hypoalbuminemia seen.

\section{DISCUSSION}

Hypoalbuminemia has been noted in most of the patients with lymphoma (1-6), progressing in severity with increasing extent and duration of the neoplastic disorder $(3,6)$. The demonstration of a reduced total circulating albumin in most of our patients with low serum albumin concentrations accords with Steinfeld's (7) findings in twelve patients with various neoplastic disorders. These results suggest that dilution due to plasma volume expansion was not a major factor in the reduced serum albumin concentrations observed.

Another factor of importance is the distribution of albumin between the intravascular and extravascular compartments. In the three patients studied with large protein-rich effusions, there was a marked decrease in the percentage of albumin within the intravascular space, with a consequent reduction in the serum albumin concentration despite normal or elevated total body albumin pools. A similar decrease in the percentage of intravascular body albumin has been noted in patients with cirrhosis and ascites (18) and with idiopathic chylous effusions (19). Freeman and Mathews (20) have indicated that an estimate of the total body pool by the methods of Berson and co-workers (13) used for the present study may be unreliable if the protein breakdown is confined to the intravascular compartment, since the specific activity of the protein would not be uniform throughout the body. The magnitude of the error is a function of the rates of protein turnover and the rate of exchange between the extravascular and intravascular compartments. In patients with nephrosis this error is exceedingly large (21). When the protein survival $t_{\frac{1}{2}}$ is long, however, as in the present study, the error is not significant. In the three patients with effusions, the specific activity of the albumin of the pleural fluid was almost identical with that of the serum after 9 days (Table IV), indicating that the equilibration of the $\mathrm{I}^{131}$-albumin between the body compartments required for calculation of the total body albumin pool size had occurred.

The fraction of the body pool of $\mathrm{I}^{131}$-albumin degraded per day was within the normal range in fifteen of the patients without effusions and was slightly increased in two cases (Patients 9 and 16). A moderate increase in the fractional rate of albumin catabolism has been noted in animals and man in association with steroid administration (22), fever (22), and in the hypermetabolic states $(23,24)$. Patient 9 had a range of basal metabolic rates from $51.7 \mathrm{kcal}$ per $\mathrm{m}^{2}$ per hour $\left(+34\right.$ per cent) to $56.3 \mathrm{kcal}$ per $\mathrm{m}^{2}$ per hour ( +46 per cent $)$ in three determinations, but had a protein bound iodine of $6.1 \mu \mathrm{g}$ per $100 \mathrm{ml}$, whereas Patient 16 was receiving $200 \mathrm{mg}$ of prednisolone during the study, possibly explaining the increased rate of albumin catabolism seen in these subjects.

In the three patients with large protein-rich effusions, there was a significant reduction in the fraction of the body pool of $\mathrm{I}^{131}$-albumin degraded per day. Campbell, Cuthbertson, Mathews, and McFarlane (25), Lewallen, Berman, and Rall (26), Veall and Vetter (27), and Berson and Yalow (18) report that albumin degradation occurs only in the intravascular compartment or in a small, rapidly exchanging, extravascular com- 
partment. This may explain the reduced fractional catabolic rate in these patients with effusions who have a reduction in the percentage of intravascular body albumin. The albumin turnover data in the present study may be expressed as the percentage of intravascular albumin degraded per day according to the method of Veall and Vetter (27). The patients with effusions degraded 11 per cent of their intravascular albumin pool per day, which is comparable to the mean values of the normal subjects (10 per cent) and of the lymphoma patients without effusions ( 12.7 per cent). This accords with the hypothesis that the amount of protein degraded depends upon the size of the circulating albumin pool and that little or no protein degradation occurs in the effusions. A comparable observation that the urinary excretion of radioactivity parallels the plasma radioactivity and has no correlation with the activity in the extravascular compartments, including the effusions, has been noted in patients with idiopathic chylous effusions (19) and in a patient with cirrhosis and ascites (18).

Schwartz and Jarnum (9) and Barunden and associates (10) have presented evidence suggesting that gastrointestinal protein loss was present in two patients with lymphoma and that this may be a factor in the hypoalbuminemia associated with lymphoma. None of thirty patients with lymphoma in the present study, however. had evidence of excessive gastrointestinal protein loss as measured by $\mathrm{I}^{131}$-albumin turnover, or $\mathrm{I}^{131}-\mathrm{PVP}$, or both. This is of interest, since two of the patients had gastric infiltration with lymphoma, causing distortion and ulceration of the mucosa, and one patient had severe hypogammaglobulinemia, diarrhea. steatorrhea, and biopsy evidence of dilated lymphatics of the intestinal mucosa. These features are frequently associated with loss of protein into the gastrointestinal tract. Many of the other patients had gastrointestinal symptoms, and most had tumor involvement of the retroperitoneal lymph nodes as shown by X-ray or autopsy examination.

Our studies suggest that the major factor in the hypoalbuminemia seen in patients with lymphoma is diminished albumin synthesis. This agrees with the studies of Steinfeld (7), who also found defective albumin synthesis in patients with neoplastic disease. Deficient caloric intake, malab- sorption, liver damage, and nitrogen trapping by the tumor have been suggested as potential causes of deficient protein synthesis in patients with tumors. During this study, only two patients had a deficient caloric intake, and only one had significant weight loss. Patient 18 is the only one in whom malabsorption may have been a factor in the hypoalbuminemia. Liver functions were not sufficiently deranged in our patients to explain the consistent hypoalbuminemia. Only seven patients had abnormal liver function tests, and these abnormalities were relatively minor in degree. No information can be derived from the present study on the possibility that amino acids are diverted from albumin synthesis to tumor growth, as postulated by some investigators $(28,29)$. Hypoalbuminemia is, however, a common accompaniment of many nonneoplastic chronic inflammatory diseases where tumor trapping of precursor nitrogen could not be a factor. Thus, although malnutrition, malabsorption, disturbed liver function, and diversion of nitrogenous precursors for tumor growth may play roles in the deficient albumin synthesis seen in these patients, none of these factors would appear to explain fully this defect in albumin synthesis.

\section{SUM M ARY}

1. Albumin metabolism was studied in 30 patients with lymphoma by use of $\mathrm{I}^{131}$-labeled albumin, or $I^{131}$-polyvinylpyrrolidone, or both.

2. Serum albumin concentration, total circulating albumin, and total body albumin pools were reduced in 13 of the 17 patients without effusions who were studied with $\mathrm{I}^{131}$-albumin.

3 . The 3 patients with large protein-rich effusions had low serum albumin concentrations and low total circulating albumin values but normal or increased total body albumin pools, indicating that an abnormal distribution of albumin between the intravascular and extravascular compartments was the major factor in the reduced serum albumin concentrations.

4. The fraction of the body albumin degraded per day was normal in 15 and slightly increased in 2 of the patients without effusions.

5. The fraction of the body albumin pool degraded per day was reduced in each of the 3 patients with effusions. 
6. None of the patients had evidence of excessive gastrointestinal protein loss.

7. Each patient with a low serum albumin concentration had reduced albumin synthesis. This defect in albumin synthesis appears to be the major factor in the hypoalbuminemia in this group of patients with lymphoma.

\section{REFERENCES}

1. Petermann, M. L., Karnofsky, D. A., and Hogness, K. R. Electrophoretic studies on the plasma proteins of patients with neoplastic disease. III. Lymphomas and leukemia. Cancer 1948, 1, 109.

2. Rottino, A., Suchoff, D., and Stern, K. G. Electrophoretic study of the blood serum from lymphogranulomatous patients. J. Lab. clin. Med. 1948, 33,624 .

3. Mider, G. B. Alling, E. L., and Morton, J. J. The effect of neoplastic and allied diseases on the concentrations of the plasma proteins. Cancer 1950, 3, 56.

4. Arends, T., Coonrad, E. V., and Rundles, R. W. Serum proteins in Hodgkin's disease and malignant lymphoma. Amer. J. Med. 1954, 16, 833.

5. Neely, R. A., and Neill, D. W. Electrophoretic studies on the serum proteins in neoplastic disease involving the haemopoietic and reticulo-endothelial systems. Brit. J. Haemat. 1956, 2, 32.

6. Boggs, D. R., and Fahey, J. L. Serum-protein changes in malignant disease. II. The chronic leukemias, Hodgkin's disease, and malignant melanoma. J. nat. Cancer Inst. 1960, 25, 1381.

7. Steinfeld, J. L. $\mathrm{I}^{131}$ albumin degradation in patients with neoplastic diseases. Cancer 1960, 13, 974.

8. Jarnum, S., and Schwartz, M. Hypoalbuminemia in gastric carcinoma. Gastroenterology 1960, 38, 769.

9. Schwartz, M., and Jarnum, S. Protein-losing gastroenteropathy. Dan. med. Bull. 1961, 8, 1.

10. Barandun, S., Aebersold, J., Bianchi, R., Kluthe, R., von Muralt, G., Poretti, G., and Riva G. "Proteindiarrhöe" zugleich ein Beitrag zur Frage der sogenannten essentiellen Hypoproteinamie. Schweiz. med. Wschr. 1960, 90, 1458.

11. Gornall, A. G., Bardwill, C. J., and David, M. M. Determination of serum proteins by means of the biuret reaction. J. biol. Chem. 1949, 177, 751.

12. Henry, R. J., Goluk, O. J., and Sobel, C. Some of the variables involved in the fractionation of serum proteins by paper electrophoresis. Clin. Chem. 1957, 3, 49.

13. Berson, S. A., Yalow, R. S., Schreiber, S. S., and Post, J. Tracer experiments with $\mathrm{I}^{181}$ labeled human serum albumin: distribution and degradation studies. J. clin. Invest. 1953, 32, 746.

14. Steinfeld, J. L. Difference in daily albumin synthesis between normal men and women as measured with $\mathrm{I}^{131}$-labeled albumin. J. Lab. clin. Med. 1960, 55, 904.
15. Gordon, R. S., Jr. Exudative enteropathy: abnormal permeability of the gastrointestinal tract demonstrable with labelled polyvinylpyrrolidone. Lancet 1959, 1, 325.

16. Briner, W. H. A note on the formulation of iodine $\mathrm{e}^{131}$ labelled polyvinylpyrrolidone for intravenous administration. J. nucl. Med. 1961, 2, 94.

17. Rutstein, D. D., Ingenito, E. F., and Reynolds, W. E. The determination of albumin in human blood plasma and serum. A method based on the interaction of albumin with an anionic dye-2-(4'hydroxy-benzeneazo) benzoic acid. J. clin. Invest. 1954, 33, 211.

18. Berson, S. A., and Yalow, R. S. The distribution of $I^{131}$ labeled human serum albumin introduced into ascitic fluid: analysis of the kinetics of a three compartment catenary transfer system in man and speculations on possible sites of degradation. $\mathrm{J}$. clin. Invest. 1954, 33, 377.

19. Waldmann, T. A. Unpublished data.

20. Freeman, T., and Mathews, C. M. E. Analysis of the behavior of $\mathrm{I}^{131}$ albumin in the normal subject and nephrotic patient. Sonderbänd zur Strahlentherapie 1958, 38, 283.

21. Gitlin, D., Janeway, C. A., and Farr, L. E. Studies on the metabolism of plasma proteins in the nephrotic syndrome. I. Albumin, $\gamma$-globulin and iron-binding globulin. J. clin. Invest. 1956, 35, 44.

22. Flick, A. L., and Steinfeld, J. L. The effect of fever and corticotropin on the in vivo degradation of albumin in man as measured with iodinated human serum albumin. Amer. J. med. Sci. 1958, 236, 65.

23. Rothschild, M. A., Bauman, A., Yalow, R. S., and Berson, S. A. The effect of large doses of desiccated thyroid on the distribution and metabolism of albumin- $\mathrm{I}^{131}$ in euthyroid subjects. J. clin. Invest. 1957, 36, 422.

24. Lewallen, C. G., Rall, J. E., and Berman, M. Studies of iodoalbumin metabolism. II. The effects of thyroid hormone. J. clin. Invest. 1959, 38, 88.

25. Campbell, R. M., Cuthbertson, D. P., Mathews, C. M., and McFarlane, A. S. Behaviour of ${ }^{14} \mathrm{C}$ and ${ }^{131} \mathrm{I}-$ labelled plasma proteins in the rat. Int. J. appl. Radiat. 1956, 1, 66.

26. Lewallen, C. G., Berman, M., and Rall, J. E. Studies of iodoalbumin metabolism. I. A. Mathematical approach to the kinetics. J. clin. Invest. 1959, 38, 66.

27. Veall, W., and Vetter, H. Radioisotope techniques in clinical research and diagnosis. London, Butterworth, 1958, pp. 318-340.

28. Mider, G. B., Tesluk, H., and Morton, J. J. The effects of Walker carcinoma 256 on food intake, body weight and nitrogen metabolism of growing rats. Acta Un. int. Cancr. 1948, 6, 409.

29. LePage, G. A., Potter, V. R., Busch, H., Heidelberger, C., and Hurlbert, R. B. Growth of carcinoma implants in fed and fasted rats. Cancer Res. 1952, 12, 153. 